\title{
Furnace Device
}

National Cancer Institute

\section{Source}

National Cancer Institute. Furnace Device. NCI Thesaurus. Code C49965.

An enclosed chamber designed to produce heat. 